\title{
Concept of sensory garden in the revitalization project of a housing estate in Krasnystaw
}

\section{Margot Dudkiewicz}

https://orcid.org/0000-0002-3762-6192

margotdudkiewicz@o2.pl

\section{Patryk Krupiński}

patrykrupinski@gmail.com

\section{Sylwia Czapla \\ czapelka539@gmail.com}

Department of Landscape Architecture, Department of Horticulture and Landscape Architecture, University of Life Sciences in Lublin

\section{Cyprian Moryc \\ kursikony@gmail.com}

The Sacred Art Workshop St. Bernardine and Bl. Nicholas

at the Passion-Mary Sanctuary in Kalwaria Zebrzydowska

\begin{abstract}
Sensory gardens are places designed to stimulate the senses. Most often they are designed near hospitals and schools, where due to availability of the garden, people suffering from sensory processing disorders (autism, dementia, depression) can enjoy new experiences in a safe and comfortable environment. The purpose of the study was to show the possibility of introducing a sensory garden also to the housing estate. The city of Krasnystaw is located $50 \mathrm{~km}$ south of Lublin. By carrying out an inventory of existing vegetation and study work, project guidelines were developed. One of the social aspects of the work was to create a garden, that is to integrate the residents. The plant material was selected having in mind senses specification, including hearing, smell and sight. Architectural elements (lighting, benches, gazebo) that were missing so far have been designed, using mainly natural materials - stone and wood. The project selected decorative species of trees and shrubs in terms of colors and forms of leaves, flowers, fruits and an interesting conformation.
\end{abstract}

Keywords: revitalization, sensory garden, Krasnystaw

\section{Introduction}

Revitalization is a procedure aiming at removing degraded areas that have lost their original functions from the crisis state, taking into account their natural conditions and potential of a given place (Dz.U. 2015 pos. 1777, Krupiński and Pudelska 2018). This process involves reviving an object or space by giving it new usable features and increasing visual values. Revitalization of urban areas may concern both the protection of historical forms and modern landscapes (Przesmycka 2005). Social participation plays a very important role in the revitalization process. Participation involves residents in the activities and decisions taken in local communities. It is a process, in which the residents' requirements and remarks regarding changes in the area, they will use in the future, are taken into account (Hausner 1999, Pawłowska 2010). 
Residential estate makes the largest share in the urban space. Quality of the housing space should be considered in the context of the city, including the processes taking place in it. Many factors determine the nature of environment and quality of residents' life. High quality of housing space is very important from the perspective of people who live in a given place of residence on a daily basis (Wojtkun 2004, Lorens 2005, Pawłowska 2008a). When designing complexes of multi-family buildings, at least $30 \%$ of the area should be a biologically active area (Regulation of the Minister of Infrastructure of April 12, 2002). The estate greenery has protective, relaxing and aesthetic functions. The project of estate greenery in block building should include areas for quiet rest, play areas for children and youth, sports grounds and greenery associated with economic devices. According to the norms concerning green areas in Poland, there is $15 \mathrm{~m}^{2}$ per one inhabitant, meanwhile in Western Europe it is $40 \mathrm{~m}^{2}$ (Kasińska and Sieniawska-Kuras 2009). The areas of estate greenery are biologically active areas surrounded by residential buildings, roads and public facilities. The presence of greenery between blocks is necessary, because it introduces a color accent, warms the rawness of buildings and improves the overall image of the place (Malczyk 2012).

When designing the space next to a residential building, one should focus on preserving the elements that connect a given community, leaving space for social initiatives and predicting the needs of residents, that land development not only does not limit people, but also gives them the opportunity to shape their space. Due to this, one can break the impersonal use of space in a residential complex inhabited by strangers. This is related to the term "taming" of a space, consisting in the transformation of environment, giving or restoring the functional, social, cultural and aesthetic order, and ensuring a sense of security and belonging (Ossowska 2014).

\section{Forms and functions of estate greenery}

Public space is available to all users - it is under general social control. These include: street areas, parks, sports grounds, gardens. Private space is the enlargement of the flat with adjacent backyard greenery. These are mini-gardens used by residents, but also terraces, gardens on the roofs and balconies. The semi-public space connects small groups of acquainted people (neighbours), a small community characterized by a common system of values, similar lifestyle, and a sense of proximity. There are such development elements as: partially closed courtyards, areas of common use (playgrounds, rest gardens), technical areas, car parks (Kimic 2011, Chmielewski 2012).

Green interiors are limited by residential buildings, public facilities (shops, schools), housing roads, parking lots, etc. Housing development is often accompanied by unfavourable conditions for vegetation such as strong shading, air pollution, sterilized soils and potential risks of mechanical damage. Compact housing estate and dense network of underground technical installations are an obstacle mainly for the root system of trees. Despite many unfavourable factors, the presence of greenery in interiors is most desirable. The trees soften the harshness of buildings, hide the uninteresting neighbourhood, and shadow the car parks. In the case of small interiors, low and medium greenery is introduced with single accents of high greenery, usually evergreen. The selection of vegetation that accompanies housing development should fulfill a specific function. Species should be attractive for most of the year, due to which residents will be more willing to identify with the surrounding space. Plants should have interesting properties, i.e. habit, leaf texture, bark or fruits. The basic recommended species for planting in a housing estate are: decorative apple tree, red oak, rowan, birch, linden, larch and fir. The project should also include shrubs such as dogwood, forsythia, jasmine, sumac, spiraea and juniper (Pokorski and Siwiec 1999, Zaber and Urbański 2005).

Plants are an important factor in improving the quality of environment. They purify the air by absorbing carbon dioxide and oxygen production in the process of photosynthesis. Due to the ability of phytoremediation or absorbing harmful substances from the environment by accumulating them in leaves or shoots, greenery is a barrier that isolates residential buildings from dust and exhaust from streets. Many plants extract bacteria and fungi by isolating the phytoncides (Zaber and Urbański 2005). Greenery negatively ionizes and moisturizes the air, which has a beneficial effect on the process of breathing and blood circulation. It lowers stress and positively affects the nervous system (Szulc 2013, Dudkiewicz et al. 2018). Studies have shown that people living close to open green spaces are more physically active, healthier and less prone to lifestyle diseases caused 
by stress. Being surrounded by nature affects positively both the physical and mental condition of a person (Nowak 1997, Lohr and Relf 2000, Nowak 2005, Di Nardo et al. 2010).

In a sense, every garden can be called a sensory garden, because it stimulates all human senses in part. Most people focus their attention only on the visual aspect, ignoring the smell or texture of plants. A sensory garden is a composition designed in such a way that the non-visual stimuli are maximally stimulated. This treatment is especially important for people affected by vision diseases, but not only. The remaining users can therefore look at the garden from a different point of view than before (Pawłowska 2008b). The main assumption of sensory gardens is the impact on human senses: smell, sight, touch, hearing and taste. Gardens of senses have a relaxing effect, improve the psycho-physical condition of users, and allow to recharge with positive energy, so valuable to our well-being.

Introducing sensory gardens to housing estate has a positive impact on residents. It calms and makes time for people, who rest in the garden (e.g. after returning from work). In addition, location of aromatic plants near the windows allows residents to enjoy a pleasant smell in the apartment. Even when going out for a walk, passing by a fragrant rebate, one can relax and calm down. Using sensory gardens, the estate area can be more functional, diverse in terms of color and nature, friendly for resting people or playing children. In the spring, when nature comes to life, man after the winter is more sensitive to smell and color stimuli, more willingly spends time in the open air. To make this time pleasant, fragrant plants can be planted along pedestrian routes, benches or arbors, so that a nice fragrance can be found where the person most often lives. In the case of monotonous, gray buildings, the space can be enlivened by introducing vivid, warm colors (red, orange, yellow). However, in places saturated with colors (e.g. with numerous banners, signs), subdued, cool colors are proposed, soothing the character of the surroundings (green, blue, purple, gray). Especially in the case of children, the ability to touch soft sand, refreshing water or rough bark shapes their senses, encourages learning new things, stimulates the imagination.

The aim of the work was to show the possibility of introducing a sensory garden to the housing estate of Krasnystaw city in Lublin region.

\section{Material and methods}

This study is of a review and design nature. Field studies, questionnaire surveys and design works were used. The research was carried out in 2016-17. Field work consisted of creating a detailed dendrological inventory and photographic documentation. Determination of tree and shrub species was made in accordance with Seneta and Dolatowski (2012). The local vision was to define a group of users using the site, functional, spatial and viewing analysis. Due to an interview with residents of the surrounding buildings - an analysis of the users' needs was made. Study work allowed for development of design guidelines.

\section{Results}

The site of the study is located in Krasnystaw at Szkolna Street, and its area is $9500 \mathrm{~m}^{2}$. The block of flats in the center of the plot is a five-story building of the 1990s, consisting of nine repetitive segments.

A detailed dendrological inventory showed that all 64 specimens of trees and shrubs growing in the area are in good health and require only minor care treatments. Tree stand is represented by 12 species of trees, mainly common rowan Sorbus aucuparia (8 pcs.), northern white-cedar Thuja occidentalis (1 pc. and 2 hedges), common fir Picea abies (8 pcs.). There are also particularly decorative trees in the spring and autumn, i.e. wild apple Malus sylvestris (2 pcs.), apple tree Malus (3 pcs.), mirabelle plum Prunus domestica (2 pcs.) and bird cherry Cerasus avium (5 pcs.). Noteworthy is also very decorative sessile oak Quercus petraea (1 pc.). Other species are: silver birch Betula pendula (3 pcs.), common ash Fraxinus excelsior (3 pcs.), European larch Larix europaea (2 pcs.) and blue spruce Picea pungens ( 1 pc.).

Along the main communication routes, there are short viewing axes. There are no compositional axes in the field created from plant systems or surfaces. Scenic openings from the block windows cover a large part 
of the area, but they are disturbed by accidentally placed devices in the playground. On a small elevation, two potentially interesting viewing points in the south-eastern part of the area were specified.

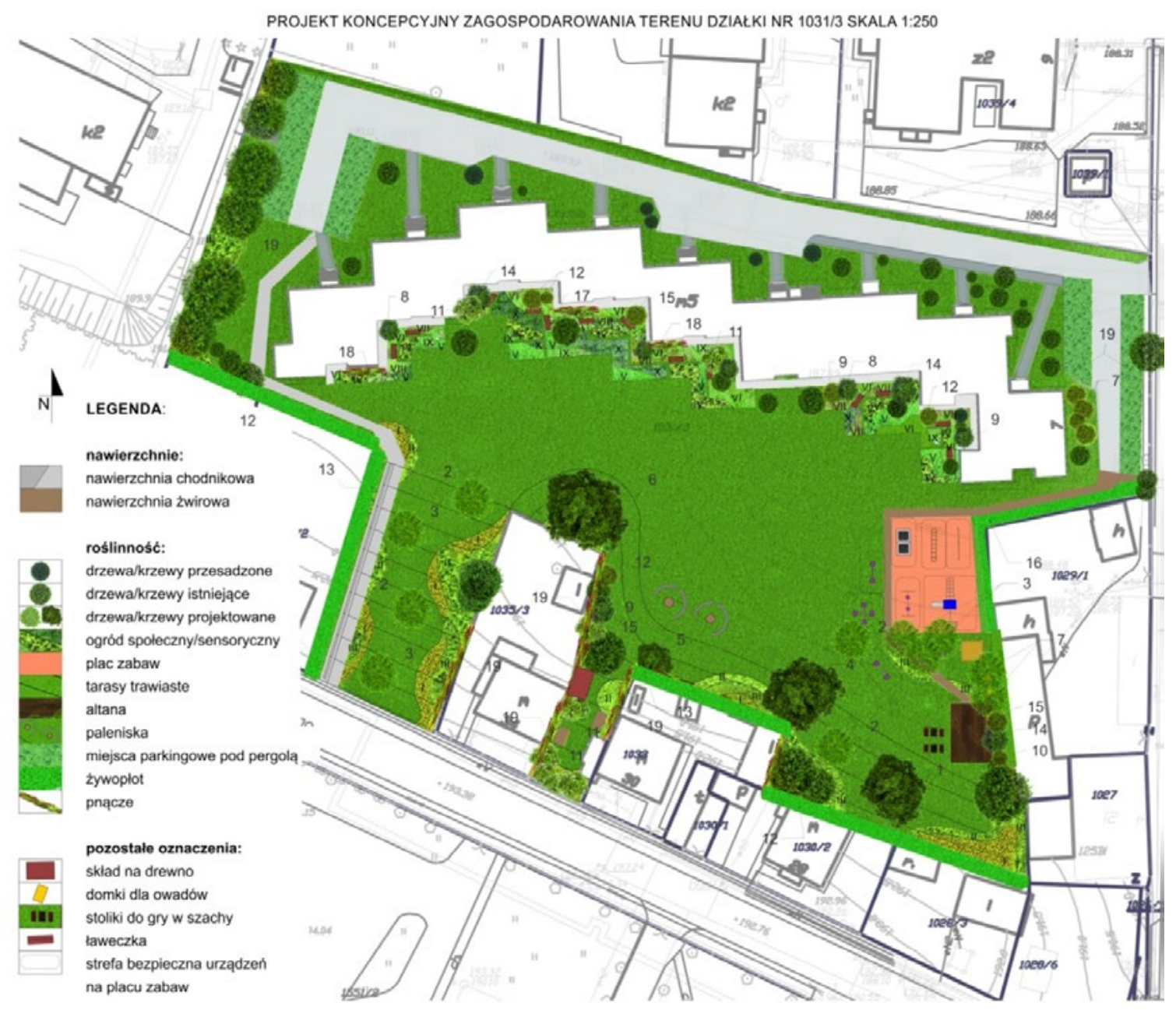

Fig. 1. Concept design of revitalization of the development area (developed by S. Czapla)

The project assumes division of land into individual zones and introduction of new plants recommended for sensory gardens (Fig. 1). In the northern part, the communication zone has been left (carriageways and parking spaces). Existing lighting with the surface has been preserved. The area has been extended with additional space for bicycles. Parking spaces are covered with a pergola that is overgrown with a five-leaf chervil. The main entrances to the buildings were decorated with decorative shrubs. Aromatic lawns are planned near the balconies (Fig. 2). In the southern part, the main arrangement of communication paths has been preserved, which has been extended to include existing ones. In the southern part, a slope with a wall for sitting was formed using grassy terraces. A large gazebo and two fireplaces have been planned nearby (Figs. 3 and 4). The composition is completed by planting ornamental grasses and trees with great aesthetic qualities, including birches and plane trees with decorative bark. The playgrounds have been divided, taking into account the age of users. Older people were given larger equipment, while for the youngest, a place was laid out on the sodden turf among decorative plants. The ecological zone in the southern part of the plot serves as a refuge for insects and birds. There are many useful plants there, such as narrow-leaved lavender, coneflower, and butterfly bush. The whole area is to be open to users and act as social gardens. Such a procedure is aimed at encouraging people to get in touch with nature and to improve contacts between residents. The project uses plants that are resistant to urban conditions and do not require complex care treatments. 
Despite various forms of land use, plant material is an element connecting all zones. The characteristic elements for the whole assumption are plantings of ornamental grasses. In addition to its natural, gentle nature, the grass has a soothing effect on humans through the sound of leaves in the wind. Distribution of grasses focuses on the most important landscape points, such as the lonely tree or decorative cherry plantings. In the recreation and landscape part, new plantings from higher trees were proposed in order to introduce shading of the area and as natural elements shaping the landscape. Trees of various species were used, decorative in various aspects: plane-tree (decorative bark, leaves, fruits), lime (decorative flowers, fruits), oak (decorative leaves, habit), chestnut (decorative leaves, flowers, fruits), birch (decorative bark, conformation). In addition to decorative values, the fruits of lime, chestnut and plane tree can be used by children to play. On the southern side, the area is partly surrounded by hedge plantings: western thistle, early spurge, scarlet fire. The proposed plants, in accordance with the assumption of sensory gardens, enjoy due to their fragrance (lavender, echinacea, sage, mugwort, lilac), color (geranium, tritium, coneflower, crinoids, hydrangea), soothe with their leaves with murmuring (cress, millet). Plants were collected in several groups, complementing each other. The whole project is characterized by the selection of suitable species for urban conditions, well-composed in the group and with similar requirements.
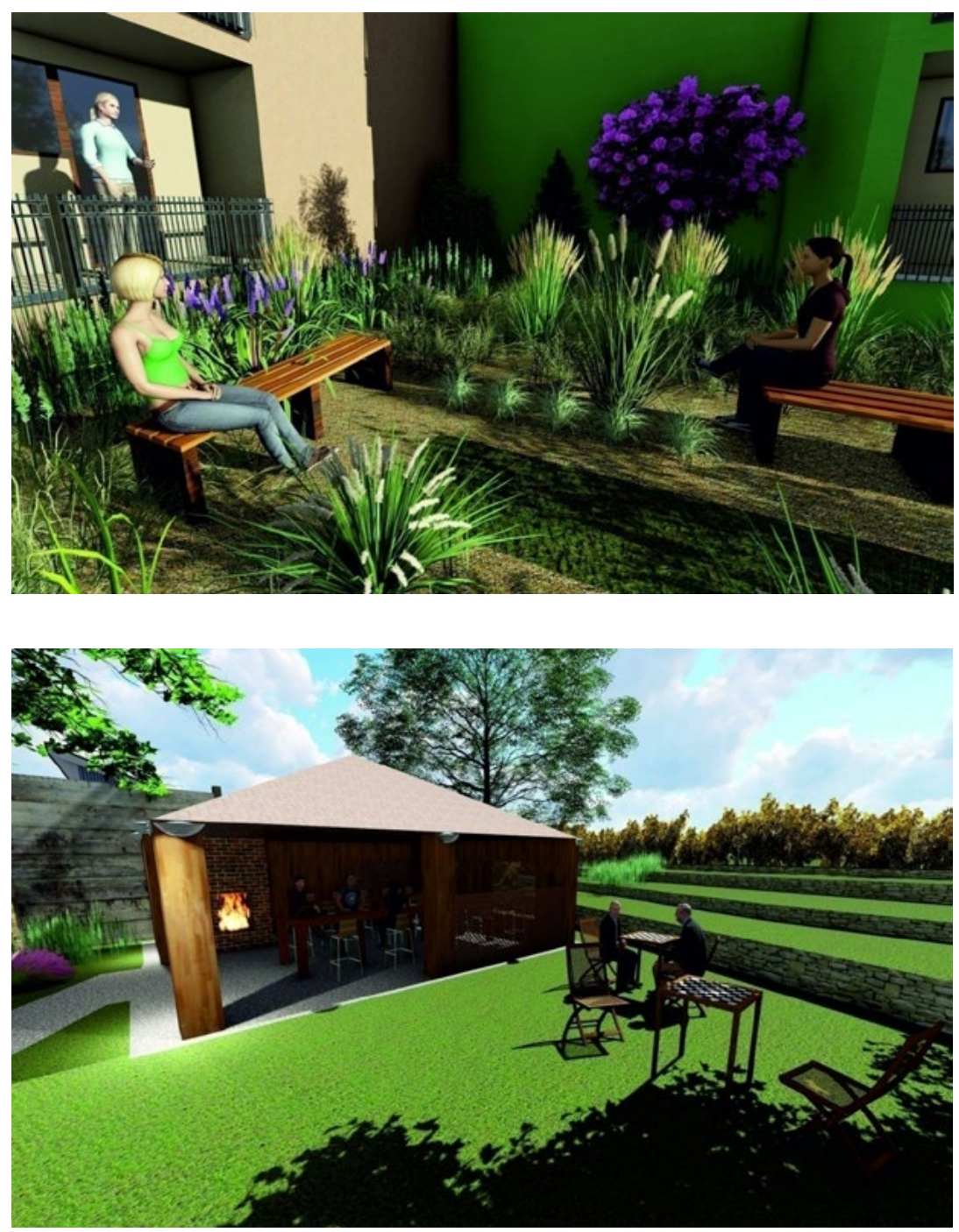

Fig. 2. Visualizations of the new vision of the estate - flowerbed under balconies (developed by S. Czapla)

Fig. 3. Visualizations of the new vision of the estate - gazebo and chess tables (developed by S. Czapla) 


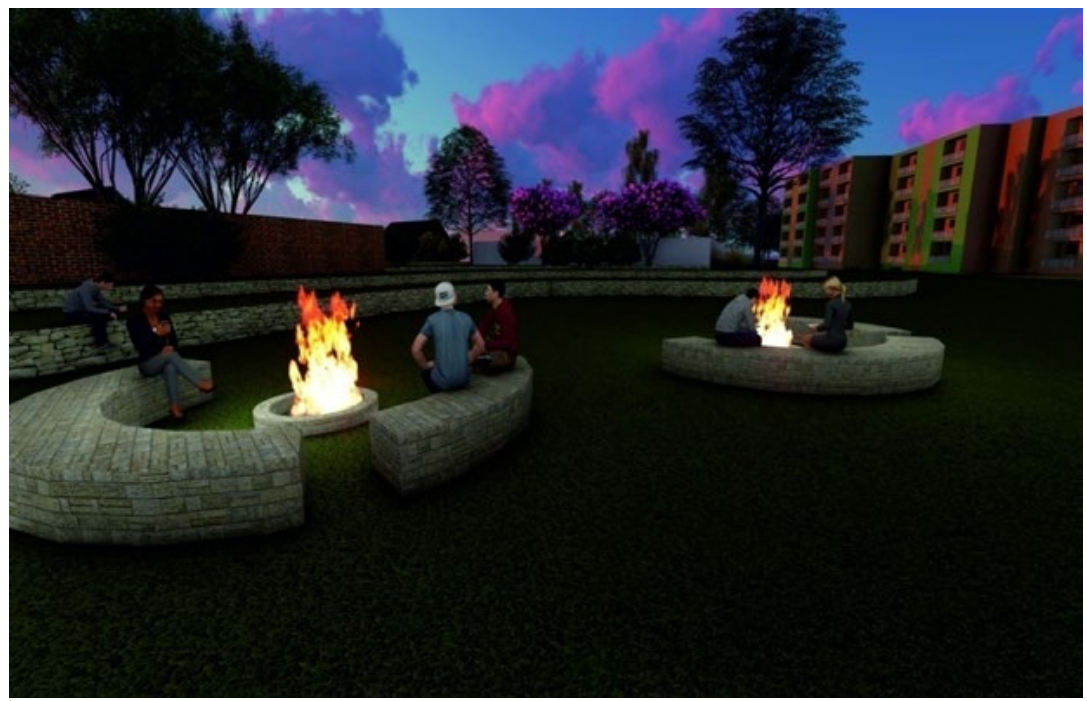

Fig. 4. Visualizations of the new vision of the estate - fireplaces and terraces on a slope (developed by S. Czapla)

\section{Summary}

The project of housing estate revitalization at Szkolna Street in Krasnystaw is aimed at improving the comfort of residents. The new layout and division of environment into individual zones will allow the use of the area in accordance with the requirements of residents. Currently, surrounding of the apartment block is developed solely with a view to basic needs. Lack of division into functions in the southern part of the site limits the rational use of land by users. Lack of basic elements of small architecture of lighting and planting with ornamental plants allow for only small social activities in the area of the square. Despite the occurrence of greenery (mainly at the borders of the plot), the area appears empty and undeveloped, creating an atmosphere of anonymity in the urban space. Development plan, in accordance with the above assumptions, will favourably improve the functionality of the area. By designating the appropriate zones, spatial order will prevail. The introduction of new plantings (sensory flowerbeds, grassy terraces, creepers, trees) will benefit the enrichment of the area in terms of nature, aesthetics and society.

\section{References}

[1] Chmielewski T 2012. Systemy krajobrazowe Struktura - Funkcjonowanie - Planowanie, PWN, Warszawa

[2] Dudkiewicz M., Pudelska K., Parzymies M., Durlak W. 2018. Rola hortiterapii i bukieciarstwa w leczeniu dzieci i dorosłych. Kosmos 4: - w druku.

[3] Haber Z., Urbański P. 2005. Kształtowanie terenów zieleni z elementami ekologii, Wydawnictwo Akademii Rolniczej im. Augusta Cieszkowskiego w Poznaniu, Poznań.

[4] Hausner J. 1999. Komunikacja i partycypacja społeczna. Małopolska Szkoła Administracji Publicznej Akademii Ekonomii w Krakowie, Kraków, 40-42.

[5] Kasińska L., Sieniawska-Kuras A. 2009. Architektura krajobrazu dla każdego. Wydawnictwo i Handel Książkami KaBe s.c.

[6] Kimic K. 2011. Struktura przestrzeni osiedli mieszkaniowych jako podstawa kształtowania ich zagospodarowania przestrzennego - wybrane koncepcje podziału przestrzeni osiedlowych [w:] B. Szulczewska, R. Giedych (red.), Przestrzeń przyrodnicza i społeczna osiedli mieszkaniowych w XX i XXI wieku, Wydawnictwo SGGW, Warszawa 93-102.

[7] Krupiński P., Pudelska K. Projekt rewitalizacji terenu przy Pałacu Potockich w Lublinie Teka Kom. Arch. i Urb. Stud. krajobr. - OL PAN - w druku.

[8] Lorens P. (red) 2005. Problem suburbanizacji. Bibioteka urbanisty, Warszawa, s. 6-8.

[9] Ossowska L, Janiszewska D. 2014. Podstawy gospodarki przestrzennej, Wydawnictwo Uczelniane Politechniki Koszalińskiej, Koszalin. 
[10] Pawłowska K. 2008a. Przeciwdziałanie konfliktom wokół ochrony i kształtowania krajobrazu. Wyd. Politechniki Krakowskiej, Kraków, 57-59.

[11] Pawłowska K. 2008b. Dźwięk w krajobrazie jako przedmiot badań interdyscyplinarnych. Prace Komisji Krajobrazu Kulturowego, T. XI, Instytut Nauk o Ziemi UMCS, Komisja Krajobrazu Kulturowego PTG, Lublin, 143-152.

[12] Pawłowska K. 2010. Zanim wybuchnie konflikt. Idea i metody partycypacji społecznej w ochronie krajobrazu i kształtowaniu przestrzeni. Fundacja Partnerstwo dla Środowiska, Kraków.

[13] Pokorski J., Siwiec A. 1999. Kształtowanie terenów zieleni, WSiP, Warszawa.

[14] Przesmycka E. 2005. Rewitalizacja przyrodnicza miast - kontynuacja czy dyskontynuacja. Teka Kom. Arch. Urb. Stud. Krajobr. - OL PAN vol. I: 53-59.

[15] Rozporządzenie Ministra Infrastruktury z dnia 12 kwietnia 2002 r. w sprawie warunków technicznych, jakim powinny odpowiadać budynki i ich usytuowanie (Dz.U. Nr. 75, poz. 690).

[16] Seneta W., Dolatowski J. 2012. Dendrologia. Wydawnictwo Naukowe PWN, Warszawa.

[17] Szulc A. 2013. Zielone Miasto zieleń przy ulicach. Wyd. Agencja Promocji Zieleni Sp. z o.o.

[18] Ustawa o rewitalizacji z dnia 9 października 2015 r. (Dz.U. 2015 poz. 1777).

[19] Wojtkun G. 2004. Osiedle mieszkaniowe w strukturze miasta XX wieku. Wyd. Politechniki Szczecińskiej, Szczecin, $18-31$.

[20] Zaber Z., Urbański P. 2005. Kształtowanie terenów zieleni z elementami ekologii. Wydawnictwo Akademii Rolniczej im. Augusta Cieszkowskiego, Poznań. 